\title{
The Tamaraw (Bubalus (B.) mindorensis) Hemoglobin Phenotype and Comparison among the Asian Buffaloes Based on Isoelectric Focusing
}

\author{
Chester D SOLIS, Yoshi KAWAMOTO*, Kazuaki TANAKA, \\ Joseph S MASANGKAY**, Kei-ichiro MAEDA \\ and Takao NAMIKAWA \\ School of Agricultural Sciences, Nagoya University, \\ Chikusa-ku, Nagoya-shi 464-01 \\ * Primate Research Institute, Kyoto University, Inuyama-shi 484 \\ ** College of Veterinary Medicine, University of the Philippines \\ at Los Baños, Laguna, 4031, the Philippines
}

(Received June 16, 1995)

\begin{abstract}
Hemoglobins (Hb) from seven captive tamaraws were examined and compared to that of water buffaloes (Bubalus bubalis) : five river type and eleven swamp type; and two species of anoas: two lowland anoas (Bubalus (Anoa) depressicornis H. Smith, 1827) and eight mountain anoas $(B .(A$.$) quarlesi Ouwens, 1910) using ultrathin polyacrylamide gel isoelectric focusing$ (PAGIF). The Hb phenotype of the tamaraws displayed a monomorphic single band, compared to two bands (major and minor bands) in water buffaloes and one to three allelic bands found in polymorphic anoa individuals. We designate this band $\mathrm{Hb}^{\text {Tamaraw }}$, having the highest isoelectric point (pI) focused at the same level as the minor band. Dissociation of globin chains by urea-PAGIF showed that Hb $\mathrm{Hb}^{\text {Tamaraw }}$ consists of a single type of $\alpha$ and $\beta$ globins, whose $\alpha$ focused at the same pl level as the $\alpha$ minor band of water buffalo, as it is also true between the single $\alpha$ band of the anoa and the $\alpha$ major band of water buffalo focused at a lower pI. The $\beta$ band of the tamaraw shared the same pI level to the $\beta$ bands of both the water buffaloes and lowland anoas. The $\mathrm{Hb}^{\text {Tamaraw }}$ differs by having a single $\alpha$ component from that of the water buffaloes, and an $\alpha$ band with a higher pl level from that of the anoas.
\end{abstract}

Anim. Sci. Technol. (Jpn.) 66 (12) : 1014-1018, 1995

Key words : Bubalus mindorensis, tamaraw, water buffalo, hemoglobin, isoelectric focusing

The tamaraw (Bubalus (B.) mindorensis Heude, 1888$)^{6.7)}$ is an endangered wild buffalo which can only be found in the island of
Mindoro, the Philippines. Various nomenclatures including Bubalus arnee mindorensis ${ }^{9)}$ and Anoa mindorensis ${ }^{5)}$ have been given to this rare

タマラオ (Bubalus (B.) mindorensis) へモグロビンの等電点電気泳動法による表現型とアジアスイギュウのそれ

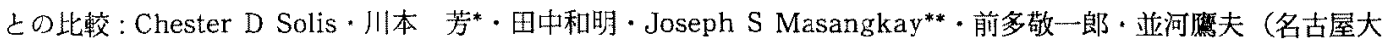
学農学部, 名古屋市下種区 646-01, *京都大学靃長類研究所, 犬l市 484, **フィリピン大学獣医学部, ラグナ 県 4031) 
species as incurred by the insufficient knowledge to its basic biological character. Up to the present, its precise taxonomic classification remains elusive, yet crucial for its active conservation. Presently it is classified under the Asian buffalo group ${ }^{10)}$ which include the Anoa of Sulawesi in Indonesia and the water buffalo, however the exact divergence process of this group is yet unclear. Based on few characters and at morphological level, they have been placed under the genus Bubalus, where the tamaraw and the water buffalo fall under the subgenus Bubalus, while the two species of anoas fall under subgenus $A n o a^{67}$. At molecular level, several studies on the hemoglobin of buffaloes have been made using various electrophoretic methods $s^{2,4,11,14,15)}$. In this paper, we describe the analysis of tamaraw hemoglobin phenotype for the first time and compare it with the other Asian buffaloes using the more resolutive ultrathin polyacrylamide gel isoelectric focusing (PAGIF) to increase knowledge on its genetic character and confer significant genetic insights in understanding the divergence process among these Asian buffaloes.

\section{Materials and Methods}

Blood samples were collected in EDTA tubes from seven captive tamaraws from Mindoro, the Philippines, sixteen water buffaloes (five river type and eleven swamp type) from Indonesia and the Philippines, and ten anoas (two lowland anoas and eight mountain anoas) kept at Indonesian zoos. Hemolysates and globin components were prepared according to a previous method $^{3)}$ with slight modification. Ultrathin polyacrylamide gel isoelectric focusing (PAGIF) was carried out in a $200 \mu \mathrm{m}$-thick gel at $5-8 \mathrm{pH}$ gradient, then stained with Coomassie Brilliant Blue R-250 after fixation with $10 \%$ trichloroacetic acid according to the manufacturer's instruction (Pharmacia LKB Biotechnology, Uppsala, Sweden). Focusing was performed on an isoelectric focusing (IEF) flat bed apparatus with focusing condition at
$30 \mathrm{~W}$ constant power, maximum voltage of $1,500 \mathrm{~V}$ for $60-90 \mathrm{~min}$. Globin chains were analyzed by an ultrathin urea-PAGIF gel which contains $8 \mathrm{M}$ urea. Focusing was carried out at the same constant power and voltage for $120 \mathrm{~min}$. The same staining procedure was employed.

\section{Results}

Figure $1 \mathrm{~A}$ shows the tetrameric Hb phenotype patterns of the Asian buffaloes by ultrathin PAGIF at 5-8 $\mathrm{pH}$ gradient. The tamaraw $\mathrm{Hb}$ displayed uniformly single major band focused at an approximate pI level 7.2-7.3. We designate this single band as the $\mathrm{Hb}^{\text {Tamaraw }}$ in the present paper. In comparison with the other Asian buffaloes, the water buffaloes showed two bands, a minor band having the same $\mathrm{pI}$ with the $\mathrm{Hb}^{\mathrm{Tamaraw}}$, and a major band $(\mathrm{pI}=7.0-7.1)$ with lower $\mathrm{pI}$ together with one to three different band types in anoas $\left(\mathrm{pI}=6.8^{-}\right.$ 7.1).

Dissociation of the $\mathrm{Hb}$ molecules using ultrathin urea-PAGIF revealed two constituent globin chains in tamaraw, corresponding to single $\alpha$ globin with high pI and single $\beta$ globin with low pI (Fig. 1B). The tamaraw $\alpha$ globin ( ${ }^{\mathrm{T}} \alpha$ ) band together with the $\alpha$ minor $\left({ }^{11} \alpha\right)$ band of the water buffaloes were observed to have same pI at the highest level among all the globin bands. Anoas also showed single $\alpha$ globin $\left({ }^{\mathrm{A}} \alpha\right)$ band with a different $\mathrm{pl}$ from that of ${ }^{\text {II }} \alpha$ but the same as the $\alpha$ major ( $\alpha$ ) band of the water buffaloes. The $\beta$ globin of the tamaraw, howcver apparently showed the same pl with those of the rest of the buffaloes examined, except for some mountain anoas, e.g. MA-2, MA-5 and MA-6, which show polymorphic $\beta$ alleles (Fig. 1 B).

\section{Discussion}

The resolving power of the methods used in the present study clcarly revealed the electrophoretic phenotype of the tamaraw $\mathrm{Hb}$. designated as $\mathrm{Hb}^{\text {Tamaraw }}$, which we assume to 


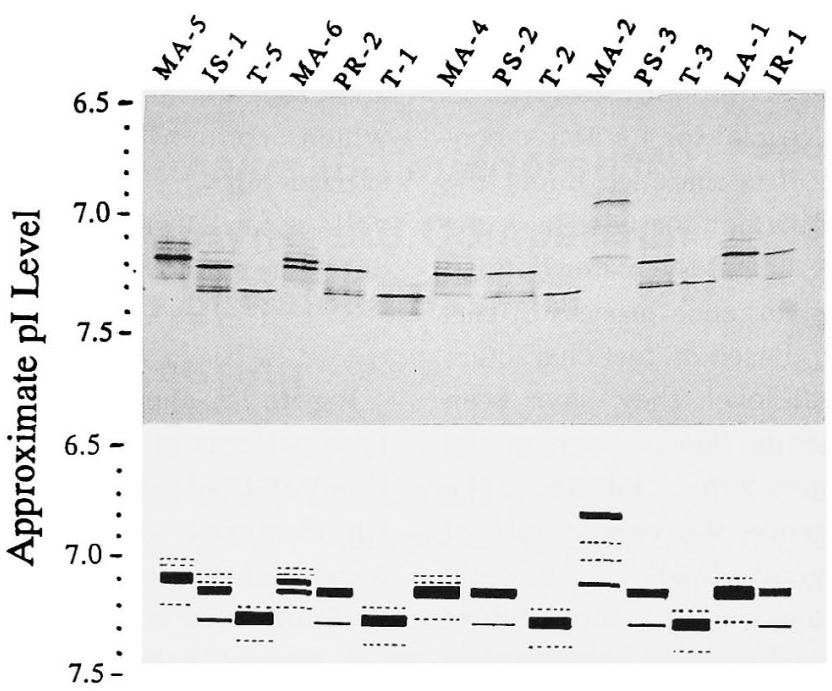

Fig. $1 \mathrm{~A}$. Comparative electrophoretic $\mathrm{Hb}$ phenotype (with diagram) among the representative Asian buffaloes $(\mathrm{T}=$ tamaraw, $\mathrm{LA}=$ lowland anoa, $\mathrm{MA}=$ mountain anoa, IS=swamp type from Indonesia, $P S=$ swamp type from the Philippines, IR= river type from Indonesia and $P R=$ river type from the Philippines of water buffaloes) focused on the ultrathin PAGIF at 5-8 pH gradient. Bands not identified are represented by broken lines.

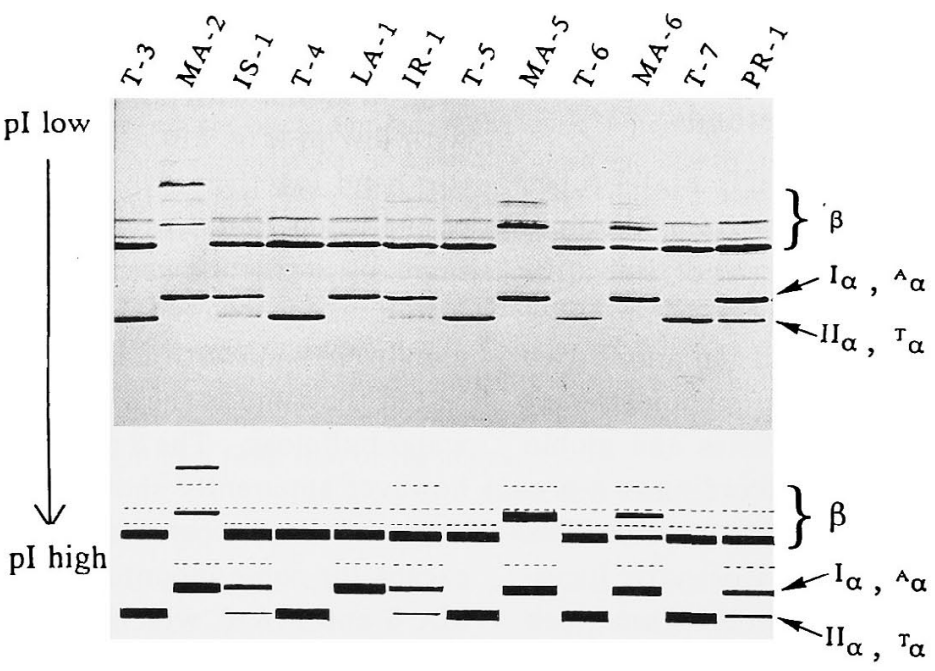

Fig. $1 B$. Comparative electrophoretic analysis (with diagram) of the $\mathrm{Hb} \alpha\left({ }^{\mathrm{T}} \alpha=\right.$ tamaraw $\alpha,{ }^{\mathrm{A}} \alpha=$ anoa $\alpha,{ }^{\mathrm{l}} \alpha=\alpha$ major and ${ }^{\mathrm{II}} \alpha=\alpha$ minor of water buffalo) and $\beta$ globin constituents among the Asian buffaloes ( $\mathrm{T}=$ tamaraw, $\mathrm{LA}=$ lowland anoa, $\mathrm{MA}=$ mountain anoa, IS = swamp type from Indonesia, $\mathrm{PS}=$ swamp type from the Philippines, $I R=$ river type from Indonesia and $P R=$ river type from the Philippines of water buffaloes) by ultrathin urea-PAGIF at 5-8 pH gradient. Bands not identified are represented by broken lines. 
consist a unique single molecular form of tetrameric $\alpha^{2} \beta^{2}$. The separation method further allowed us to ascertain the presence of one type of $\alpha$ and $\beta$ dissociated globin chains. The appearance of minor bands (not identified) similar to those observed in other studies ${ }^{4,11,15)}$ is a phenomenon recognized to be widespread and common in such technique of very high resolution which frequently resolves proteins into many more bands. Consequently, as compared with other techniques, the present results remain to be reliable which were more definely demonstrated consistent with the previous studies elsewhere using conventional electrophoresis and isoelectric focusing $4,8,11,14,15$ ).

The $\mathrm{Hb}^{\text {Tamaraw }}$ displayed a phenotype pattern evidently distinct despite its close relationship to the other buffaloes examined, as revealed by the methods used. Notable differences observed among these Asian buffaloes lie upon their $\alpha$ globin chains. The water buffaloes have two kinds of $\alpha$ globins ( ${ }^{1} \alpha$ and ${ }^{\text {II }} \alpha$ ), while the tamaraws consist of only one kind with similar pI with that of ${ }^{\text {II }} \alpha$. The anoas also focused a single $\alpha$ band, however with a pattern having similar pI with the ${ }^{\mathrm{I}} \alpha$ band. The two $\alpha$ globins in water buffaloes are known to be under the control of two structural loci as a result of duplication of $\alpha$ globin locus ${ }^{14}$. The ${ }^{\text {II }} \alpha$ differs from ${ }^{\mathrm{I}} \alpha$ as previously described, by three amino acid substitution, and having higher positive net charge and greater cathodic character ${ }^{4}$. Such $\alpha$ globin fashion among these Asian buffaloes poses some interesting inquiries on their evolutionary relationship. On the other hand, although the $\beta$ globin bands of these buffaloes displayed similar pl, the water buffaloes differ from the lowland anoa by two amino acid residues, despite no charge difference observed in electrophoresis, thus claiming a significant differentiation between the two species ${ }^{8)}$.

It is also interesting to note that these tamaraws showed the absence of $\mathrm{Hb}$ polymor- phism. This may indicate low degree of genetic variability in the tamaraw population. The maintenance of genetic variability in a small population is important in reducing homozygosity and inbreeding depression ${ }^{\mathrm{l}}$. Thus such findings relating to its population structure may prove useful to confer considerable insights aiming for the effective breeding and management of captive colonies and conservation of endangered species.

Very few studies have inferred some basic biological characteristics on this animal. Based on measurement of external characters, the tamaraw exhibited values in between the water buffaloes and the anoas; while based on karyotypes, only the tamaraw and the swamp type buffalo showed proximity by sharing the same fundamental number $(\mathrm{FN}=58)$ among the bubaline species ${ }^{13)}$. Likewise, behavioral pattern of the captive tamaraws indicated that they demonstrate similarity with the water buffaloes in several behavioral parameters observed $^{12)}$.

The tamaraw exhibits uniqueness in its $\mathrm{Hb}$ phenotype among the Asian buffalo group as evidenced by its distinct $\alpha$ globin band. Employing isoelectric focusing to analyzc $\mathrm{Hb}$ phenotype as a genetic marker can be useful in the differentiation of Asian buffalo species as well as potentially to demonstrate the degree of genetic variability in their populations. However detailed primary structural level analysis of its $\mathrm{Hb}$, as well as analyses extending to other genetic markers may provide further understanding on the evolutionary relationship of these globin genes and to the genetic character and phylogeny of the tamaraw and the rest of the Asian buffaloes.

\section{Acknowledgment}

We sincerely thank Dr. V.G. Momongan (IAS -CA), Dr. M.F. Manuel (Dean, CVM) and the staff of CVM-ADDL at UPLB for the facilities and assistance; the officers and technicians of the Tamaraw Conservation Project at Mindoro 


\section{SOLIS, KAWAMOTO, TANAKA, MASANGKAY, MAEDA and NAMIKAWA}

for the invaluable source of samples; and help from Mr. H. Nagabukuro. This research is supported by grants from the Inui Memorial Trust for Research on Animal Science, and from the Fund for Global Environment through the Nagoya Foundation of Animal Science (Dr. T. Tomita, director).

\section{References}

1) Alderson GLH. A system to maximize the maintenance of genetic variability in small populations. In : Genetic Conservation of Domestic Livestock vol. II. (Alderson L, Bodo I eds.) 18-29. $\mathrm{CAB}$ International. Wallingford, UK. 1992.

2) Balani AS, Barnabas J. Polypeptide chains of buffalo hemoglobins. Nature, 205 : 1019-1021. 1965.

3) Chernoff AI, Pettit NM Jr. The amino acid composition of hemoglobin. III. A qualitative method for identifying abnormalities of the polypeptice chains of hemoglobin. Blood, 24 : 750-756. 1964.

4) Di Luccia D, Iannibelli L, Ferranti P, Iorio M, Annunziata M, Ferrara L. Water buffalo (Bubalus bubalis) hemoglobins: An electrophoretic and chromatographic study. Comp. Biochem. Physiol., 94 B : 71-77. 1989.

5) Fischer H, Hohn H. Der karyotyp eines weiblichen tamarau (Anoa mindorensis). Giess. Beitr. Erbpathol. Zücht. hyg., 6 : 173-177, 1976.

6) Groves CP. Systematics of the anoa (Mammalia, Bovidae). Beaufortia (Series of Miscellaneous Publications, Zoological Museums of the University of Amsterdam, No. 223), $17: 1-11$. 1969.

7) Grubb P. Artiodactyla : Bovidae : bovinae. In : Mammals Species of the World : A Taxonomic and Geographic Reference. 2nd ed. (Wilson DE, Reeder DAM eds.) 377-414. Smithsonian Institutional Press. Washington and London. 1993.
8) Kakoi H, Namikawa T, Takenaka O, Takenaka A, Amano T, Martojo H. Divergence between the anoas of Sulawesi and the Asiatic water buffaloes, inferred from their complete amino acid sequence of hemoglobin $\beta$ chains. $Z$. zool. Syst. Evolut.-forsch., 32 : 1-10. 1994.

9) Klös $H-G$, Wünschmann $A$. The wild and domestic oxen. In: Grzimek's Animal Life Encylopedia. (Grzimek B ed. in chief) 331-398. 13 (Mammals IV). Van Nostrand Reinholt Com. pany, New York, Cincinnati, Toronto, London, Melbourne. 1972.

10) Mahadevan P. Distribution, ecology and adaptation. In : World Animal Science. (Holmes JHG, Tulloh NM eds.) 1-12. C 6 (Buffalo Production). Elsevier Science Publishers B. V., Amsterdam, The Netherlands. 1992.

11) Masina $P$, Ianneli $D$, Iorio $M$, Ramunno L. Hemoglobin polymorphism in Italian water buffalo (Bubalus bubalus (Arnee)). Anim. Blood Grps Biochem. Genet., $8: 65-72.1977$.

12) Momongan VG, Walde GI. The behavioral pattern of tamaraws (Bubalus mindorensis Heude) in captivity during the dry and wet seasons. $A$ study conducted under the Tamaraw Conservation Program, University of the Philippines at Los Bafios, Philippines, 1-22. 1993.

13) Namikawa $T$, Masangkay JS, Maeda $K-I$, Escalada R, Hirunagi K, Momongan VG. External characters and karyotypes of the captive tamaraws Bubalus (B.) mindorensis, at the Gene Pool in the island of Mindoro, Philippines. J. Anim. Genet., 23 : 19-28. 1995.

14) Ranjekar PK, Barnabas J. Haemoglobin phenotypes in water buffalo (Bos bubalus) during development. Comp. Biochem. Physiol., 28: 1395-1401. 1969.

15) Schreiber A, Nötzold G, Held M. Molecular and chromosomal evolution in anoas (Bovidae: Bubalus spec.). Z. zool. Syst. Evolut.-forsch., $31: 64-79.1993$. 